absentee of the pendency of the action or unless such absentee was otherwise informed of the proceedings within the statutory period during which non-resident defendants served by publication may come in and defend.

E. G. L.

\title{
TAXATION OF SEATS ON THE STOCK EXCHANGE
}

The prevailing concept of "property" is often rudely tested in taxation cases. The rules laid down in statutes and decisions have often been constructed with the idea that property is a physical res-an object of sensation. As such, property would always have a "situs"a relation in space to other objects of sense. But a chose in action is also property, although it is not a thing or res-an object of sense. Our concept of property has shifted; incorporeal rights have become property. ${ }^{1}$ And finally, "property" has ceased to describe any res, or object of sense, at all, and has become merely a bundle of legal relations-rights, powers, privileges, immunities. Such is the case whether these relations affect the consumption and enjoyment of some particular object of sense or not.

It appears that the power of a state to levy a tax often depends upon the "situs" of property. We tax "property" whether it is tangible or intangible. Whenever the power to tax depends upon situs, we are compelled to find a situs for that which under accepted definitions can have none.

In Anderson v. Durr (I92I) 42 Sup. Ct. I $5,{ }^{2}$ the United States Supreme Court held that a seat on the New York Stock Exchange is property and may be taxed in Ohio, where its owner lived, without running counter to the Fourteenth Amendment, in spite of the fact that it may also be taxed in New York. Mr. Justice Pitney finds that membership in the Exchange includes the privilege of buying and selling in the Exchange building; the power of assignment "with qualifications"; a contractual right that the business of the association shall be conducted properly; a right that in dealings with other members commissions shall be determined by a definite rule; a privilege of holding oneself out in Ohio as a member and thereby inducing business; and some interest in the capital stock of a New York corporation owning the land and building in New York City, valued in excess of

${ }^{1}$ A right is never corporeal. Mr. Justice Holmes remarks in his dissent in the case now under discussion: "All rights are intangible personal relations. . .." Anderson v. Durr (1921) 42 Sup. Ct. 15, 18. The same shift that occurred as to "property" no doubt also occurred as to "chose in action." A chose is a thing, and no doubt chose in action once meant some specific object of sense the possession and enjoyment of which might necessitate an action at law.

${ }^{2}$ Affirming (1919) 100 Ohio St. 25I, I26 N. E. 57. See Comments (1920) 29 YALE LAW Journal, 9I6, discussing the Ohio decision and analysing the "property" involved. 
$\$ 5,000,000$. This valuable taxable property is not wholly situated in New York. "The membership is personal property, and being without fixed situs has a taxable situs at the domicil of the owner. Mobilia sequuntur personam.",

Mr. Justice Holmes dissented in an opinion of one paragraph." "The fact that all rights are intangible personal relations" does not give Ohio the power to tax either land or personal property "permanently out of the jurisdiction." He seeks for an "object of the right" and he finds it in the New York Stock Exchange building. All else is merely incidental to the "right . . . . personally to enter . . . . and to do business there." Thus the property is "localized in New York. If so, it does not matter whether it is real or personal property or that it adds to the owner's credit and facilities in Ohio. The same would be true of a great estate in New York land."

The analysis adopted by the majority of the Court indicates that some of the legal relations of the owner of a seat have no connection with the New York building as an "object." They do not constitute property in the building. The power of Ohio to tax them is scarcely to be denied merely on the ground that they are "incidental."

A state taxes property because it maintains machinery for determining the existence of rights and privileges, lending its force and machinery to compel performance by those bearing duties and refusing them as against those having privileges. We believe that those should pay who reap the advantage, and that they should pay in proportion to the number and value of their advantages. Whether in the case of land, of chattels, or of choses in action, every state holds its machinery ready for all comers. A resident of Ohio who owns New York land or a New York chattel or who makes a New York contract has Ohio rights as well as New York rights, and has Oregon rights as well as Ohio rights. These various rights (and other relations) are not necessarily identical in either number or character. Shall each state therefore have the power to tax? In theory, yes; and the amount of the tax to be paid each state should be determined by the value received from each state. Practically, however, such a system would be too complicated and expensive. ${ }^{5}$ The states that, in general, render the greatest

${ }^{3}$ Anderson v. Durr, supra at p. I7.

What are the mobilia in this case and how do they follow the domicil? Do the New York rights and privileges cross an intervening state and turn into Ohio rights and privileges? Apparently some of them do not. "Nor is plaintiff's case stronger if we assume that the membership privileges exercisable locally in New York enable that State to tax them even as against a resident of Ohio. Exemption from double taxation by one and the same State is not guaranteed by the Fourteenth Amendment; much less is taxation by two States upon identical or closely related property interests falling within the jurisdiction of both, forbidden."

"Ibid. I8. Justices Van Devanter and McReynolds concurring.

"It may seem surprising that a person who has "property" in any one state has 
service are the states where the object or res is located and the state of the owner's domicil. Upon one or both of these states is conferred the power to tax, generally to the exclusion of others. The principle upon which the choice is made is not always obvious to a non-expert. ${ }^{6}$ The present decision, giving to both states the power to tax, is not in conflict with previous decisions and is not unreasonable.

A. L. C.

\section{AGREEMENTS FOR FICTITIOUS BIDS AT AUCTIONS}

The courts generally agree that a puffer at an auction is unworthy of his hire. ${ }^{1}$ His employment is considered a fraud on honest bidders. ${ }^{2}$ Thus the general rule is that in a "sale without reserve" the employment of a puffer renders the sale voidable at the election of the bona fide purchaser. ${ }^{3}$ The same result should be reached in a "sale to the highest bidder," for at common law it was considered as a sale without reserve. ${ }^{4}$ There is a representation to the public that

property in forty states: and it may be disturbing to an already unduly harassed property owner to be told that there is a theory by which he may be taxed in forty jurisdictions. The fact is, however, that the question is merely one of sound social policy. There may be some comfort in the assurance that there is still a constitution, and that the time has not yet arrived when it is regarded as "reactionary" to believe that confiscation is not sound social policy.

It is not in the least surprising, however, for an Ohio owner of a seat on the Exchange in New York to learn that he has rights in New York and in Oregon as well as in Ohio, and that Oregon holds its courts and its united strength ready for his service in the same way that Ohio does. All that is necessary is that service of process and other jurisdictional facts should exist. The "rights" recognized and enforced in Oregon may differ in various respects from those in Ohio and in New York. For example, New York may have available procedure in rem that is not available in the other states, and a contract held valid in Ohio may be held invalid in Oregon. But there is property in each state, even though it is not identically the same property.

- Thus, bank deposits are taxable in two states, although the depositor has only a chose in action. Fidelity \& C. T. Co. v. Louisville (1917) 245 U. S. 54, 38 Sup. Ct. 40. And although mobilia sequuntur personam and are taxable at the owner's domicil, it seems that they cannot be taxed there if they acquire a "permanent" location in another state, such "permanency" being possible even though they remain movable. Union Transit Co. v. Kentucky (1905) I99 U. S. I94, 26 Sup. Ct. 36. Consider also inheritance and stock transfer taxes.

${ }^{1}$ Dealy v. Land Co. (1913) 21 Calif. App. 39, I30 Pac. I066; Walker v. Nightingale (1726, H. L.) 3 Brown P. C. 263.

${ }^{2}$ National Bank v. Sprague (1869) 20 N. J. Eq. 159; Veazie v. Williams (1850, U. S.) 8 How. I34.

${ }^{3}$ Howard v. Castle (1796, K. B.) 6 T. R. 642; Thornet v. Haines ( 1846 ) I5 L. J. Exch. 230 ; Veazie v. Williams, supra note 2 ; cf. Gregory v. U. S. Fidelity Co. (1904, Sup. Ct.) 45 Misc. II2, 9I N. Y. Supp. 595. The seller cannot avoid a sale where he has employed a puffer. Troughton v. Johnson (1804) 3 N. C. 328.

'Benjamin, Sales (6th ed. 1920) 549; Parfitt v. Jepson (1877) L. J. C. P. 529. 